\title{
Corundum Molds for Investment Casting from Refractory Alloys and Metals
}

\author{
P. A. Storozhenko, ${ }^{1,2}$ G. I. Shcherbakova, ${ }^{1,2}$ D. V. Sidorov, ${ }^{1,2}$ \\ M. S. Varfolomeev, ${ }^{1,2}$ and A. S. Murkina ${ }^{1,2}$ \\ ${ }^{1}$ SSC RF Federal State Unitary Enterprise "State Research Institute for Chemistry and Technology of Organoelement Compounds", \\ 38, shosse Entuziastov, Moscow 111123 RF, Russia \\ 2 “MATI”-K. Tsiolkovskii's Russian State Engineering University, 3, Orshanskaya street Moscow 121552, Russia
}

Correspondence should be addressed to G. I. Shcherbakova, bigpastor@mail.ru

Received 21 May 2010; Accepted 20 July 2010

Academic Editor: Marcel Ausloos

Copyright ( $) 2010$ P. A. Storozhenko et al. This is an open access article distributed under the Creative Commons Attribution License, which permits unrestricted use, distribution, and reproduction in any medium, provided the original work is properly cited.

Production procedure, physical-chemical, and performance properties of ALUMOX silica-free binder used for the production of high-heat-resistant corundum shell molds by consumable patterns employed in the production of critical molds from superalloyed reactive metals and alloys are described. ALUMOX usage allows obtaining casts from reactive metals and alloys with surface roughness up to $R_{z}<10 \mu \mathrm{m}$ (basic casts $-R_{z}>60 \mu \mathrm{m}$ ), which, in its turn, increases fatigue parameters of the material (endurance, durability).

\section{Introduction}

Contemporary development of aircraft engine building is connected with continuous improvement of performance characteristics of heat-resistant alloys for gas-turbine engine vanes. In such vanes, fabrication directional crystallization technique allowing heat-resistant alloys quality improvement by means of transverse grain boundaries removal is used. However, at directional crystallization and single crystal blade casting exclusive requirements to shell molds are imposed in terms of flame resistance, durability, thermal conductivity, and deformational and thermochemical stability [1].

Conventional corundum shell molds based on ethyl silicate binder and containing silicon dioxide that interacts with heat-resistant alloy components and alkaline admixtures present in corundum as well as partly decomposes at high temperatures under vacuum do not comply with these requirements. Mold binder destruction occurs resulting in its weakening and porosity increase, and molten metal penetrates intergranular space forming a burning-in zone. Attempts to fabricate high-refractory (up to $2000^{\circ} \mathrm{C}$ ) monoxide mold consisting of $\alpha-\mathrm{Al}_{2} \mathrm{O}_{3}$ were restrained by the unavailability of a binder transforming into $\alpha$-alumina after calcination.

On the basis of chelated alkoxyalumoxane oligomers relatively stable in the air, the researchers of SSC GNIIChTEOS developed silica-free binder ALUMOX [2-4] used in the fabrication of high-refractory mold consisting of $\alpha-\mathrm{Al}_{2} \mathrm{O}_{3}$ only, for casting heavily alloyed steel, heat-resistant alloys, and refractory metals with directional and single crystal structures [4-8].

\section{Experimental}

Silica free ALUMOX binder was obtained by a patent [4]. Aluminum content was determined by trilonometry. Thermographic analysis (TGA) was conducted on TGA/SDTA 851 Mettler Toledo.

$\mathrm{X}$-ray phase analysis (XPhA) of organoalkoxyalumoxanes and ceramics on their basis was performed on $\mathrm{X}$ ray diffraction meter DRON-3M $\left(\mathrm{CuK}_{\alpha}\right.$-irradiation) with graphite monochromator. The X-ray diffraction meter is combined with personal computer. The experimental data 


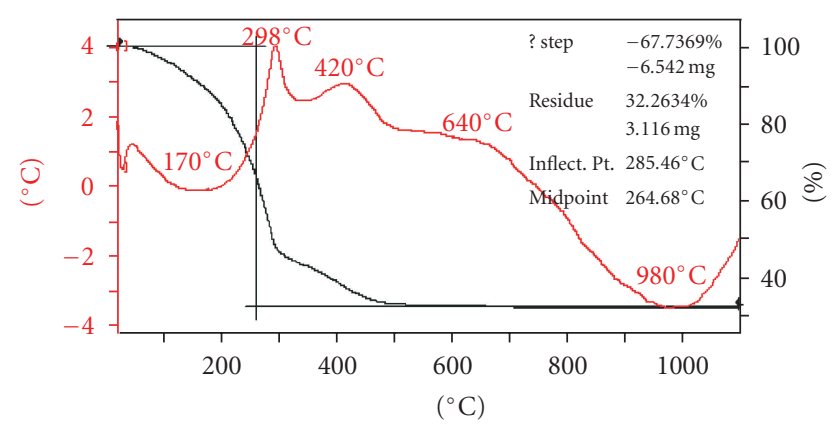

FIGURE 1: TGA and SDTA curves at ethylacetoacetatealkoxyalumoxanes pyrolysis.

were processed by KO-IMET complex. Qualitative and quantitative X-ray spectroscopic analysis was carried out using XRAYAN software and PDF (POWDER DIFFRACTION FILE) database.

Ceramic suspension was prepared according to the patents $[5,7]$. Corundum mold on ALUMOX was produced in air environment with humidity of $60 \%$ maximum. Ceramic shells were produced conventionally: consequential model immersion into suspension and its dusting with refractory granular fused $\alpha$-alumina-based material.

In order to obtain high-grade shell molds, they were dried in two independent stages: the first one-holding every layer in a high-humidity chamber till full solvent removal, the second stage-free water efflorescing from each layer.

Model composition may be removed from shell molds by any available method (hot water, pattern melt, boilerclave, or microwave heating).

Ceramic molds were calcined in a furnace at the temperature of $1250-1350^{\circ} \mathrm{C}$ within $4-6$ hours.

\section{Results and Discussions}

Researches of GNIIChTEOS investigated most promising synthesis area of organoalumoxane oligomers that were sufficiently stable in air environment and that may be used as raw material for the production of silica-free binder of $\alpha$ alumina composition [2-8].

Chelated alkoxyalumoxane oligomers were synthesized through consistent hydrolysis and alcoholysis of organoaluminum compounds in the presence of stabilizers (chelate compounds). Compounds that are characterized by ketoenol tautomerism were used as stabilizers.

Alkoxyalumoxanes (ethylacetoacetatealkoxyalumoxanes) modified by chelate compounds were synthesized according to the following scheme [2-4]:

$$
\begin{aligned}
& k \mathrm{Al}_{3}+z \mathrm{H}_{2} \mathrm{O}+s R^{*} \mathrm{OH}+x R^{* *} \mathrm{OH} \\
& \quad \longrightarrow\left[\mathrm{Al}\left(\mathrm{OR}^{*}\right)_{s}\left(\mathrm{OR}^{* *}\right)_{x}(\mathrm{OH})_{z} \mathrm{O}_{y}\right]_{k}+k R \mathrm{H},
\end{aligned}
$$

where $k=3 \div 12 ; s+x+2 y+z=3 ; R=\mathrm{C}_{n} \mathrm{H}_{2 n+1}, \mathrm{C}_{n} \mathrm{H}_{2 n+1} \mathrm{O}$, $\left(\mathrm{C}_{n} \mathrm{H}_{2 n+1}\right)_{2} \mathrm{Al}-\mathrm{O}-\left[\left(\mathrm{C}_{n} \mathrm{H}_{2 n+1}\right) \mathrm{Al}-\mathrm{O}-\right]_{m}, n=2 \div 4, m=3 \div$ $10, R^{*}=\mathrm{Et}, i-\mathrm{Pr}, n-\mathrm{Bu} ; R^{* *}=\mathrm{C}\left(\mathrm{CH}_{3}\right)=\mathrm{CHC}(\mathrm{O}) \mathrm{CH}_{3}$; $\mathrm{C}\left(\mathrm{CH}_{3}\right)=\mathrm{CHC}(\mathrm{O}) \mathrm{C}_{2} \mathrm{H}_{5}$.

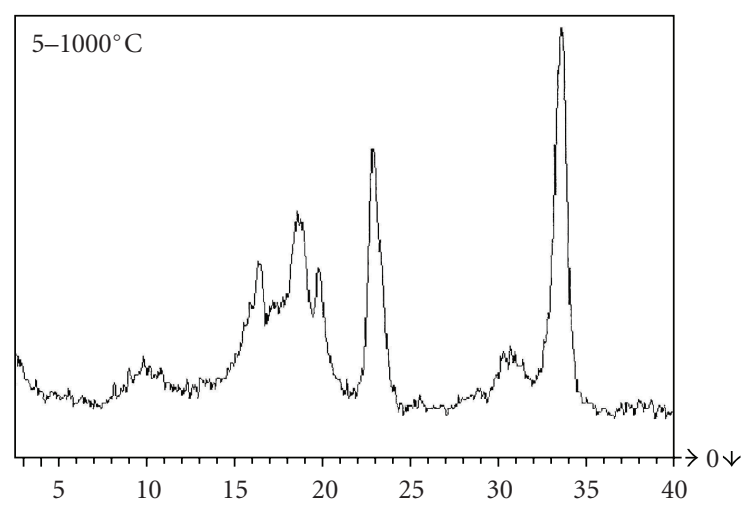

(a)

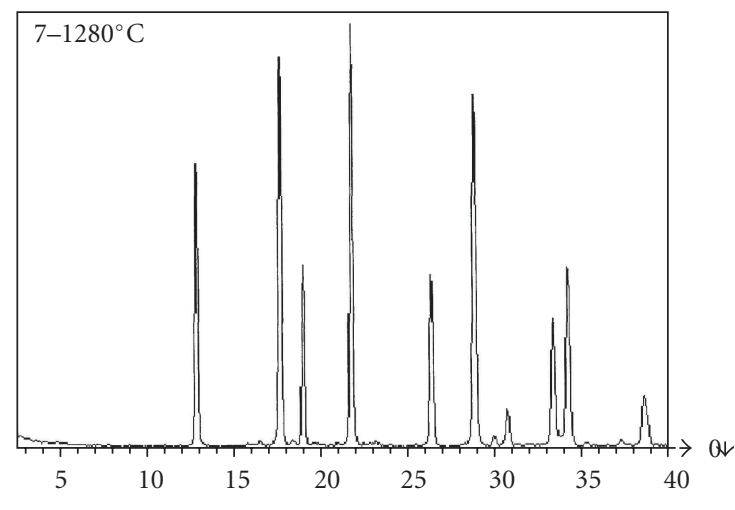

(b)

Figure 2: (a) RPhA spectrum of ethylacetoacetatealkoxyalumoxanes pyrolysis products at $1000^{\circ} \mathrm{C}$. (b) $\mathrm{RPhA}$ spectrum of ethylacetoacetatealkoxyalumoxane pyrolysis at $1200-1280^{\circ} \mathrm{C}$.

Thermal destruction of the produced ethylacetoacetatealkoxyalumoxanes was studied by thermogravimetric analysis (Figure 1).

$\mathrm{X}$-ray phase analysis showed that the sample pyrolyzed at a temperature below $900^{\circ} \mathrm{C}$ just like initial ethylacetoacetatealkoxyalumoxane was in amorphous state. Pyrolysis at $1000^{\circ} \mathrm{C}$ results in two-phase system consisting of low-temperature fine $\delta-\mathrm{Al}_{2} \mathrm{O}_{3}$ and cubic $\gamma-\mathrm{Al}_{2} \mathrm{O}_{3}$ phases (Figure 2(a)).

X-ray phase analysis (Figure 2(b)) showed that the sample pyrolyzed at $1200-1280^{\circ} \mathrm{C}$ was in crystalline state $\left(100 \% \alpha-\mathrm{Al}_{2} \mathrm{O}_{3}\right)$, so pure $\alpha$-alumina was the end product of ethylacetoacetatealkoxyalumoxanes.

On the basis of the obtained results, major thermal destruction stages may be presented by Scheme 1 .

Chelated alkoxyalumoxanes are either brittle solids or highly viscous fluids, and they cannot be used in a pure form for ceramic suspensions preparing, therefore our target was to develop such formulation that would be a fluid capable of forming suspensions with fused corundum powders of good sedimentation stability and well-wetting model compositions.

This problem was successfully solved, and on the ground of chelated alkoxyalumoxane alcoholic solution new silicafree binder [2-4] was developed; the binder when mixed with 


$$
\begin{aligned}
& \left\{\mathrm{Al}_{x}\left(\mathrm{OC}_{n} \mathrm{H}_{2 n}\right)_{y}\left[\mathrm{OC}\left(\mathrm{CH}_{3}\right)=\mathrm{CHC}(\mathrm{O}) \mathrm{OC}_{2} \mathrm{H}_{5}\right]_{z}(\mathrm{OH})_{k} \mathrm{O}_{n-k}\right\} \stackrel{80-250^{\circ} \mathrm{C}}{\underset{-y \mathrm{C}_{n} \mathrm{H}_{2 n}}{\longrightarrow}} \\
& \longrightarrow\left[\mathrm{Al}_{x}\left[\mathrm{OC}\left(\mathrm{CH}_{3}\right)=\mathrm{CHC}(\mathrm{O}) \mathrm{OC}_{2} \mathrm{H}_{5}\right]_{z}(\mathrm{OH})_{k+y} \mathrm{O}_{n-k}\right] \stackrel{300-420^{\circ} \mathrm{C}}{-z\left(\mathrm{CO}_{2}, \mathrm{C}_{2} \mathrm{H}_{4}, \mathrm{CH}_{3} \mathrm{CCH}\right)}\left[\mathrm{Al}_{x}(\mathrm{OH})_{k+y+z} \mathrm{O}_{n-k}\right] \stackrel{450-560^{\circ} \mathrm{C}}{\longrightarrow} \\
& \longrightarrow\left[\begin{array}{l}
\mathrm{Al}(\mathrm{O})(\mathrm{OH})]_{n} \mathrm{O} \\
\text { Boehmite }
\end{array}\right. \\
& -\mathrm{H}_{2} \mathrm{O}
\end{aligned}
$$

SCHEMe 1

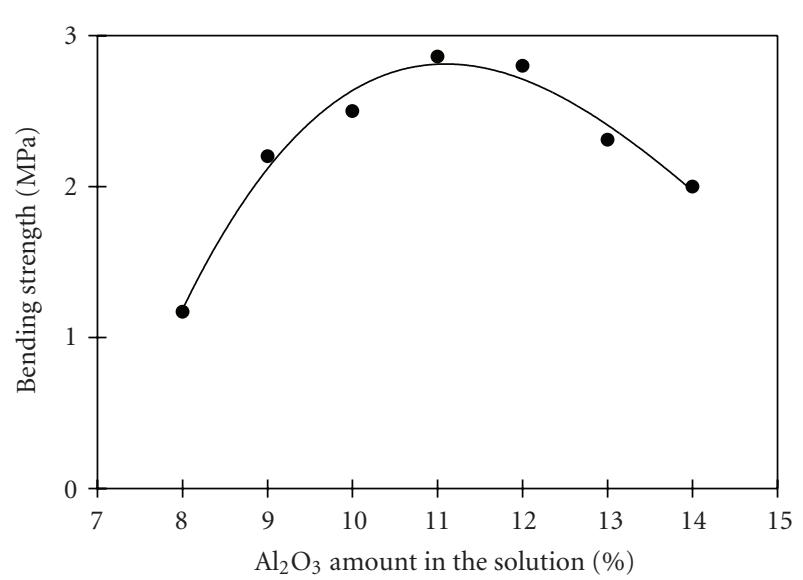

Figure 3: Ceramic samples strength as a function of $\mathrm{Al}_{2} \mathrm{O}_{3}$ content in ALUMOX.

TABLE 1: Basic characteristics of ALUMOX binder.

\begin{tabular}{lc}
\hline Characteristic & \\
\hline Viscosity of ALUMOX, $v, \mathrm{cSt}$ & $2.24-2.30$ \\
Mass fraction of $\mathrm{Al}_{2} \mathrm{O}_{3}, \mathrm{wt} \%$, & $10.0-12.0$ \\
Gel time of ALUMOX, min. & Not less than 30 \\
Relative viscosity of suspension when applied & $40-42$ \\
in 1 and 2 layers, sec. & \\
$\begin{array}{l}\text { Relative viscosity of suspension when applied } \\
\text { in 3-7 layers, sec }\end{array}$ & $28-30$ \\
$\begin{array}{l}\text { Bending strength of noncalcined shell molds, } \\
\text { MPa }\end{array}$ & $2.2-3.0$ \\
Bending strength of calcined shell molds at & $14-20$ \\
$1250-1350^{\circ} \mathrm{C}, \mathrm{MPa}$ & \\
\hline
\end{tabular}

a filler (fused corundum powders) formed ceramic suspension not tending to foaming, having enhanced sedimentation stability and well-wetting model compositions.

The silica-free binder called ALUMOX is chelated alkoxyalumoxanes solution in aliphatic alcohol of 25-35 wt $\%$ concentration, its major characteristics are presented in Table 1.

ALUMOX with $\mathrm{Al}_{2} \mathrm{O}_{3}$ content from 10 to $12 \mathrm{wt} \%$ provided ceramic sample production (without sintering activator) in noncalcined condition with maximal strength about 3.0 MPa (Figure 3).

The conducted comprehensive research proved high stability of ALUMOX and ceramic suspensions based on it as well as property retention on long storage. Thus, when stored

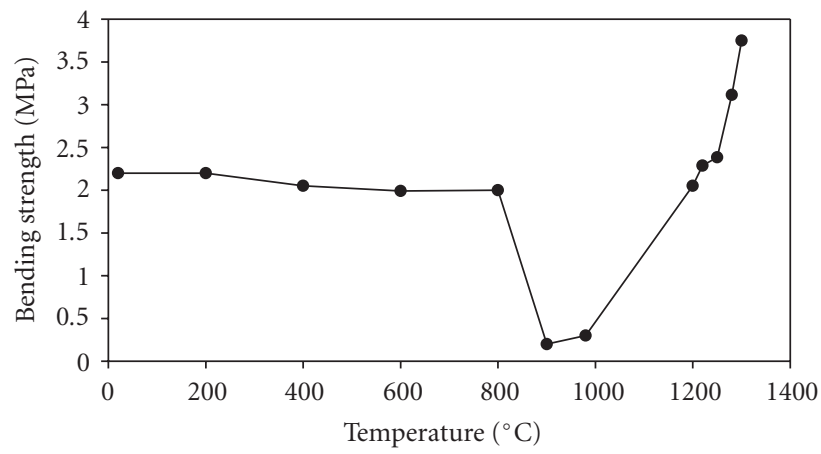

Figure 4: ALUMOX Shell Mold Mechanical Properties Dependence on Calcination Temperature.

TABLE 2: Technical features of ALUMOX.

\begin{tabular}{lccc}
\hline $\begin{array}{l}\text { Concentration } \\
\text { wt \% }\end{array}$ & $\begin{array}{c}\text { Shelf life, } \\
\text { months }\end{array}$ & $\begin{array}{c}\text { Kinematic } \\
\text { viscosity, cSt. }\end{array}$ & $\begin{array}{c}\text { Shell mold stress } \\
\text { limit, MPa }\end{array}$ \\
\hline $\mathrm{Al}=5.85$ & $1-12$ & 2.34 & 2.2 \\
$\mathrm{Al}_{2} \mathrm{O}_{3}=11.05$ & $12-24$ & 2.35 & 2.2 \\
& $24-36$ & 2.37 & 2.18 \\
\hline
\end{tabular}

in a closed container with periodical use of binder portion for various studies, ALUMOX composition and properties did not change within three years (Table 2).

$\mathrm{Al}_{2} \mathrm{O}_{3}$ content modification in binder composition results in latter viscosity and density change. Binder viscosity value allows judging about the possibility to use it for suspension production. Investigation results showed that ALUMOX viscosity did not differ from that of ethyl silicate binder that provided the possibility to use suspensions with similar filling rate. However, in contrast to the suspension based on ethyl silicate binder whose survivability constituted no more than two weeks, the survivability of ceramic suspension obtained on ALUMOX base in a tight container was retained within a year and a half (Table 3 ).

The study of ALUMOX shell molds drying kinetics demonstrated a need in two independent drying stages of different durability and different temperature depending on mold moisture content.

We found that the first drying stage must be conducted in high air humidity chamber ( $95 \%$ as a minimum) till full organic ligand removal. Oligomer molecular weight growth, $3 \mathrm{D}$ cross-linking and boehmite kind $[\mathrm{Al}(\mathrm{O})(\mathrm{OH})]_{n}$, and structure production took place therewith due to hydrolysis of alkoxy groups at $\mathrm{Al}$. 
TABlE 3: ALUMOX-based ceramic suspension bonding properties stability.

\begin{tabular}{lcc}
\hline Property & $\begin{array}{c}\text { The 1st } \\
\text { month }\end{array}$ & $\begin{array}{c}\text { The 18th } \\
\text { month }\end{array}$ \\
\hline $\begin{array}{l}\text { Relative viscosity of suspension when } \\
\text { applied in 1 and 2 layers, sec. }\end{array}$ & 40 & 42 \\
$\begin{array}{l}\text { Relative viscosity of suspension when } \\
\text { applied in 3-7 layers, sec }\end{array}$ & 28 & 28 \\
$\begin{array}{l}\text { Bending strength of noncalcined shell } \\
\text { molds, MPa }\end{array}$ & $4.2-4.8$ & $4.4-5.1$ \\
\hline
\end{tabular}

TABle 4: Relationship between ALUMOX-based shell mold mechanical properties and activator amount.

\begin{tabular}{|c|c|c|c|c|}
\hline ASD-4 amount, wt. $\%$ & 5 & 7 & 10 & 12 \\
\hline Liquid: Solid: ASD-4 & $25: 70: 5$ & $25: 68: 7$ & $25: 65: 10$ & $25: 63: 12$ \\
\hline Amount of layers & \multicolumn{4}{|c|}{6 layers completely, 7 ones without dusting } \\
\hline $\begin{array}{l}\sigma_{\text {bend. }} \text { of dry sample, } \\
\mathrm{MPa}\end{array}$ & 2.2 & 2.4 & 2.7 & 3.0 \\
\hline $\begin{array}{l}\sigma_{\text {bend. }} \text { of calcined } \\
\text { samples at } 1250^{\circ} \mathrm{C} \text {, } \\
\mathrm{MPa}\end{array}$ & 7.0 & 7.4 & 9.4 & 14.1 \\
\hline $\begin{array}{l}\sigma_{\text {bend. }} \text { of calcined } \\
\text { samples at } 1350^{\circ} \mathrm{C} \text {, } \\
\mathrm{MPa}\end{array}$ & 11.8 & 15.5 & 20.5 & 19.2 \\
\hline
\end{tabular}

The second drying stage—adsorbed moisture removalmust be conducted by means of convection drying till equilibrium moisture content in respect to environment is achieved.

ALUMOX-based shell molds must not be calcined at conventional temperatures of $900-1000^{\circ} \mathrm{C}$, as within this temperature range they actually loose strength (Figure 4) since ALUMOX at $900-1000^{\circ} \mathrm{C}$ according to XPhA data (Figure 2) is two-phase system consisting of $\delta-\mathrm{Al}_{2} \mathrm{O}_{3}$ and $\gamma$ $\mathrm{Al}_{2} \mathrm{O}_{3}$ phases.

In order to improve mechanical properties of corundum shell molds at high-temperature casting conditions, we proposed to introduce sintering activator-aluminum metal powder ASD-4 into the suspension [7, 8]. It was found that the higher is the amount of the introduced activator, the better is shell strength both in cold and calcined states thus allowing selecting optimum calcinations temperature for corundum shell molds (Table 4).

On the basis of ALUMOX binder, silica-free shell molds may be fabricated according to conventional investment casting technique. ALUMOX apparent advantage consists in the fact that it is a finished binder requiring no hydrolysis or any other reprocessing (in contrast to ethyl silicate which employment requires complex hydrolytic operation-hydrolysis in cast shops). Moreover, ALUMOX allows to produce by the conventional technique highrefractory monoxide shell mold consisting of $\alpha-\mathrm{Al}_{2} \mathrm{O}_{3}$ only, for monocrystal and aligned current structure parts casting.

It should be emphasized that in equlaxial casting processes combined shell molds, where one-two top layers are made of ALUMOX-based suspension, may be used.
Combined molds not only warrant perfect reproduction of model configuration and surface microrelief, but also the most important thing is that they make chemically inert barrier, preventing melt interaction with a shell mold (at $1600-1800^{\circ} \mathrm{C}$ ), it allows obtaining casts from reactive metals and alloys with surface roughness up to $R_{z}<10 \mu \mathrm{m}$ (basic castings have $R_{z}>60 \mu \mathrm{m}$ ). This, in its turn, improves fatigue performance of the material (strength, service life).

Thus, new manufacturing process for corundum molds by consumable patterns for refractory and reactive metal and alloys casting has been developed, regularities of $\alpha$-aluminabased ceramic composite have been investigated.

\section{Conclusion}

(1) Production technique of ALUMOX silica-free binder of $\alpha$-alumina composition based on stabilized alkoxyalumoxanes was developed.

(2) ALUMOX is a finished binder that can be stored in a sealed container for indefinite period, and there is no need in any additional adaptation under foundry conditions.

(3) ALUMOX use raises ceramic suspension survivability (suspension shelf life in a sealed container actually is not limited).

(4) ALUMOX allows obtaining monoxide high-heatresistant refractory corundum mold with required mechanical characteristics according to conventional process of investment casting.

(5) ALUMOX use for corundum-based shell molds fabrication eliminates metal penetration in metal-mold interface and provides for up to $95 \%$ raw material recycle.

\section{References}

[1] E. A. Kablov, "Cast Blades of Gas Turbine Engines (Alloys, Technology, Coatings)," M., MISIS, 2001.

[2] P. A. Storozhenko, G. I. Shcherbakova, A. S. Murkina, et al., "Organoalkoxyalumoxanes and silica free binder on their base," Neorganicheskie Materialy, vol. 43, no. 3, pp. 373-382, 2007.

[3] P. A. Storozhenko, G. I. Shcherbakova, A. M. Tsirlin, et al., "Organoaluminum and organosilicon compounds for advanced nanoceramic composites," Nanotekhnika, vol. 2, no. 14 , pp. 25-33, 2008.

[4] G. I. Shcherbakova, A. M. Tsirlin, P. A. Storozhenko, et al., "Method of Polyalkoxyalumoxanes Production, Silica Free Binder on Their Base," Russian patent no. 2276155, C07F 5/06, 2006.

[5] N. N. Korneev, G. I. Shcherbakova, V. S. Kolesov, et al., "Suspension for Ceramic Molds Fabrication by Investment Patterns," Russian patent no. 1838986 A3 USSR IPC 6 B22C1/06, B22C1/16, no. 4792668/02, 1996.

[6] N. N. Korneev, G. I. Shcherbakova, and V. S. Kolesov, "Manufacturing of Shell Moulds for Alumoxide Ceramics Molding. Mechanical Behavior of Materials-VI," in Proceedings of the 6th International Conference, pp. 71-74, Kyoto, Japan, JulyAugust 1991. 
[7] N. N. Korneev, G. I. Shcherbakova, V. G. Antashev, K. K. Yasinskii, and V. G. Gerlivanov, "Suspension for Ceramic Molds Fabrication by Investment Patterns," Russian patent no. 2082535, IPC 6 B22C1/06, B22C1/16, 1997.

[8] V. G. Antashev, A. V. Markevich, S. P. Rozhnov, and G. I. Shcherbakova, "New process development prospects of titanium castings," Liteinoe Proizvodstvo, vol. 10, pp. 17-18, 1997. 

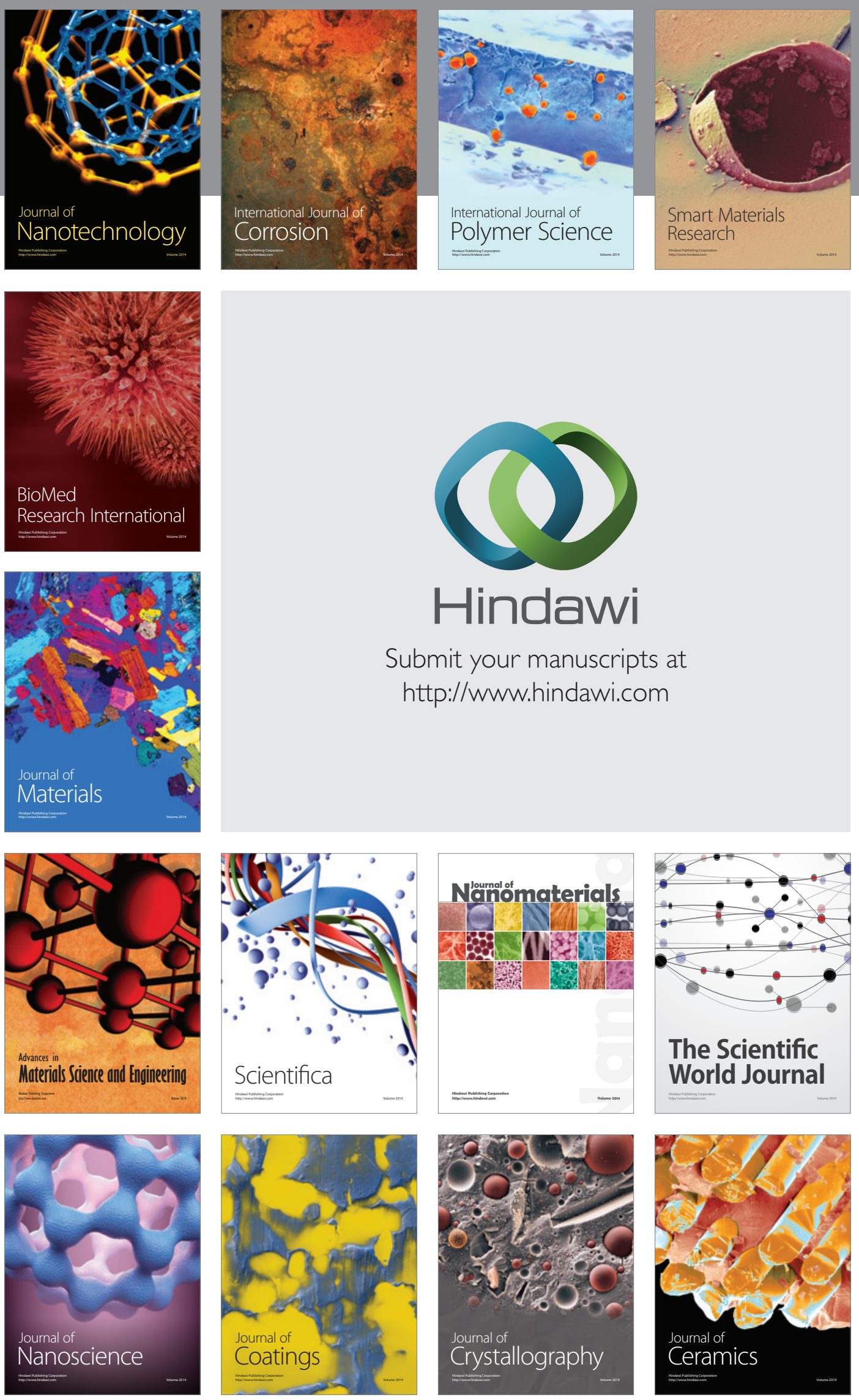

The Scientific World Journal

Submit your manuscripts at

http://www.hindawi.com

\section{World Journal}

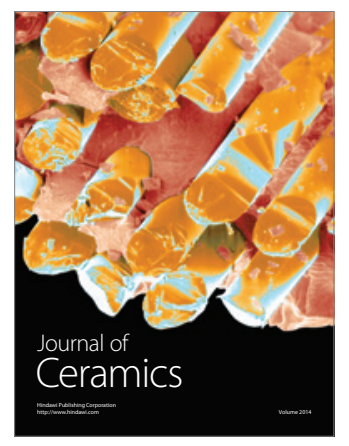

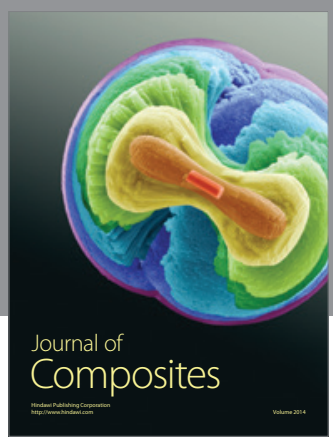
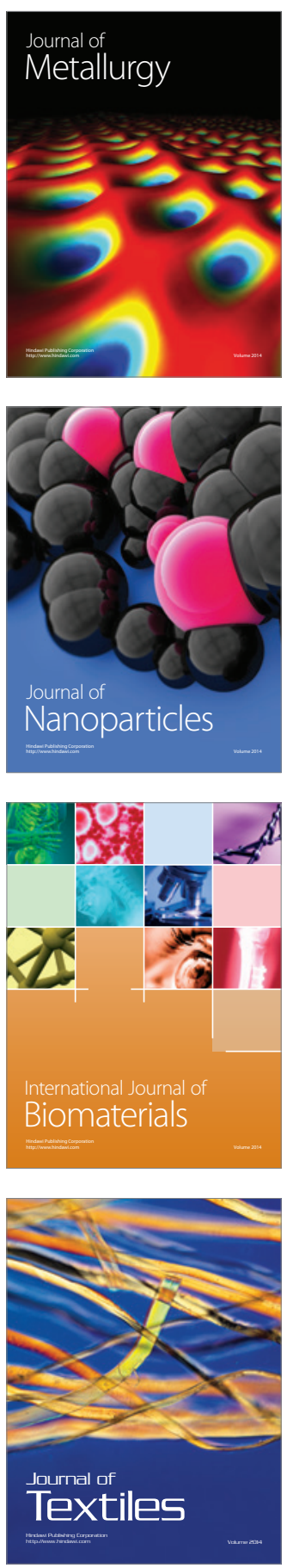